\title{
IMP3 Expression in Urothelial Carcinomas of the Urinary Bladder
}

\author{
Mesanenin Ürotelyal Karsinomlarında IMP3 Ekspresyonu
}

\author{
Nihal ÖZKALAY ÖZDEMIR, Nilay ŞEN TÜRK, Ender DÜZCAN
}

Department of Medical Pathology, Pamukkale University, Faculty of Medicine, DENIZLI, TURKEY

\begin{abstract}
Objective: Superficial tumors including Ta, Tis, and T1 make up $75 \%$ of urothelial carcinomas of the bladder. While the behavior of these superficial urothelial cancers is relatively benign, invasive tumors have a significant mortality rate. However, Ta and T1 tumors might display different biological behavior. There is therefore a great need for biomarkers that can accurately distinguish the behavior of urothelial carcinomas in addition to tumor grade and stage. Our aim was to determine the immunohistochemical expression profile of insulin like growth factor II mRNA binding Protein 3 (IMP3) and its correlation with tumor stage and grade in benign urothelium and bladder urothelial carcinomas.
\end{abstract}

Material and Method: The expression of IMP3 in 91 patients with benign urothelium (20 cases), low grade invasive (17 cases) / noninvasive (20 cases) urothelial carcinoma and high grade invasive (20 cases) / non-invasive (14 cases) urothelial carcinoma was evaluated by immunohistochemistry in this study.

Results: IMP3 was not expressed in benign urothelium, low-grade non-invasive urothelial carcinoma and high grade non-invasive urothelial carcinoma. Expression of IMP3 was found in $11.76 \%$ of low-grade invasive urothelial carcinomas and 55\% of high grade invasive urothelial carcinomas. Statistical analysis including $\chi 2$ tests showed that IMP3 expression of invasive urothelial carcinomas was statistically significant $(\mathrm{p}<0.000)$.

Conclusion: The detection of IMP3 only in invasive carcinomas although some of them were low grade showed that the expression of IMP3 may be related to aggressive behavior of urothelial carcinomas.

Key Words: Urinary bladder, Urothelial carcinoma, IMP3, Transitional cell carcinoma

\section{INTRODUCTION}

Approximately $90 \%$ of malignant tumors developing in the bladder are urothelial carcinomas derived from the urothelium (1). Superficial tumors make up $75 \%$ of the urothelial carcinomas. Superficial tumors are quite benign while a high mortality rate has been reported with invasive

Received : 25.08 .2010

Accepted : 20.10.2010

\section{Öz}

Amaç: Ürotelyal karsinomların \%75'i yüzeyel tümörler olarak Ta, Tis ve T1 şeklinde karşımıza çıkmaktadır. Yüzeyel tümörler benign davranış gösterirken, invaziv tümörlerde ise yüksek mortalite oranı bildirilmiştir. Bununla birlikte, Ta ve T1 tümörler, farklı biyolojik davranışlarsergileyebilmektedirler. Budurum, ürotelyalkarsinomların davranışının belirlenmesinde, histopatolojik evre ve dereceye ek olarak, bazı biyolojik belirteçlere ihtiyaç olduğunu göstermektedir. $\mathrm{Bu}$ çalışmada amacımız, benign ürotelyum ile mesanenin ürotelyal karsinomlarında insulin like growth factor II mRNA binding Protein 3 (IMP3) ekspresyon profilini belirleyerek, tümörün histopatolojik evresi ve derecesi ile ilişkisini saptamaktır.

Gereç ve Yöntem: Bu çalışmada 91 hastaya ait benign ürotelyum (20 olgu), düşük dereceli invaziv ( $17 \mathrm{olgu}$ ) / non-invaziv ( $20 \mathrm{olgu}$ ) ürotelyal karsinom ve yüksek dereceli invaziv (20 olgu) / non-invaziv (14 olgu) ürotelyal karsinom tanısı almış olgular immünohistokimyasal olarak IMP3 ekspresyonu açısından değerlendirildi.

Bulgular: Benign ürotelyum, düşük dereceli non-invaziv ürotelyal karsinom ve yüksek dereceli non-invaziv ürotelyal karsinom tanısı almış olgularda IMP3 ekspresyonu saptanmadı. Düşük dereceli invaziv ürotelyal karsinom olgularının \%11,76'sında, yüksek dereceli invaziv ürotelyal karsinom olgularının \%55'inde IMP3 ekspresyonu saptandı. $\chi 2$ testi ile yapılan istatistiksel analizde, invaziv tümörler ile IMP3 boyanması arasında istatistiksel olarak anlamlı ilişki saptandı $(\mathrm{p}<0.000)$.

Sonuç: Bulgularımız, düşük dereceli de olsa sadece invaziv tümörlerde IMP3 ekspresyonunun saptanması, IMP3'ün ürotelyal karsinomlarda agresif tümör davranışı ile ilişkili olabileceğini düşündürmektedir.

Anahtar Sözcükler: Mesane, Ürotelyal karsinom, IMP3, Transisyonel hücreli karsinom

tumors. The histopathological stage and grade are therefore the two most important factors in determining the behavior and treatment plan for bladder tumors $(2,3)$. However, $\mathrm{Ta}$ ve T1 tumors can exhibit different biological behavior (4). Expression of the insulin like growth factor II mRNA binding protein (IMP3) expression, studied in many other

Correspondence: Nihal ÖZKALAY ÖZDEMİR

Department of Medical Pathology, Pamukkale University, Faculty of

Medicine, DENIZLİ, TURKEY

E-mail: nihalozkalay@hotmail.com Phone: +90 2582962440 
solid organ tumors in addition to bladder tumors, has been associated with advanced stage and aggressive tumor behavior (3) .

Our aim in this study was to determine the IMP3 expression profile in benign urothelium and urothelial carcinomas of the bladder and evaluate its relationship with the histopathological stage and grade of the tumor.

\section{MATERIAL and METHOD}

We retrospectively evaluated cases diagnosed as benign urothelium, low-grade non-invasive, low grade invasive, high-grade non-invasive and high-grade invasive urothelial carcinoma on TUR material between January 2005 and January 2010 at the Medical Pathology Department of Pamukkale University Medical Faculty. We included 20 cases each in the study from 118 cases diagnosed as benign urothelium, 156 as high-grade invasive urothelial carcinoma and 37 as low-grade non-invasive urothelial carcinoma using the "random numbers table". We included all the 14 high-grade non-invasive and 17 low-grade invasive urothelial carcinoma cases in the archives in the study. The archive preparation of the 91 cases in total that had been prepared after fixation with $10 \%$ formaldehyde solution and embedding in paraffin and then stained with hematoxylineosin $(\mathrm{H} \& \mathrm{E})$ were re-evaluated.

The clinical information of the patients such as age, gender, number of tumors, tumor diameter, and type of biopsy were obtained from the pathology reports, cystoscopy reports and patient files.

All sections stained with H\&E were assessed for prognosisrelated parameters such as tumor histopathological stage and grade and lymphovascular invasion and re-evaluated according to the World Health Organization/International Society of Urologic Pathology 2004 Classification (1).

The sections that best reflected tumor tissue were determined for all cases and consecutive serial sections 4-5 $\mu \mathrm{m}$ thick were obtained from their relevant paraffin blocks for immunohistochemical IMP3 evaluation.

Section 4-5 $\mu \mathrm{m}$ thick were obtained onto electrostaticcharged slides (X-traTM, Surgipath Medical Industries, Richmond, Illinois, USA) from tissues that had been fixed in formalin and embedded in paraffin, and these were then dried at $60^{\circ} \mathrm{C}$ for at least two hours. The whole staining procedure including the deparaffinization and antigen exposure steps was performed on the Ventana, BenchMark XT fully automatic immunohistochemistry staining device. Counterstaining was completed on the device with Hematoxylin and blue-dying solution. The immunohistochemistry staining protocol was completed with dehydration, clarification with xylene and closure with a coverslip of the sections. The primary antibody used was the IMP3 monoclonal antibody (dilution: $1 / 100$, Clone: 69.1, Code: L523S, Dako SA, Glostrup, Denmark). The cytoplasmic staining observed in neuroendocrine lung carcinoma tumor cells for IMP3 in was used as positive control.

The tumor areas with the densest positive staining and thinnest section were chosen by screening the whole section with the 10x magnification of the microscope (Eclipse E200, Nikon, Japan) for each case when evaluating the immunohistochemical staining for IMP3 antibody. All cytoplasmic staining areas found in tumor cells on the sections were considered positive whether mild, moderate or severe.

All analyses were performed with the SPSS software (version 16.0, SPSS Inc., Chicago, IL, USA) and the $\chi^{2}$ test. A p value $<0.05$ for a result was accepted as significant

\section{RESULTS}

There were a total of 82 patients aged 28 to 96 with 9 females (male/female: 9/1) and a mean age of $61.80 \pm 13.27$ years. All cases were re-evaluated according to the WHO 2004 classification. The 20 cases in the high-grade invasive urothelial carcinoma group showed lamina propria invasion (pT1) in 8 cases and muscularis propria invasion (pT2) in 12 cases. Muscularis propria was present in 2 of the 8 cases with lamina propria invasion (pT1) in the high-grade invasive urothelial carcinoma group while the muscularis propria had not been sampled in 5 . We had a total of 14 cases with high-grade non-invasive ( $\mathrm{pTa}$ ) urothelial carcinoma in the archive and all were included in the study. We included 20 cases from the low-grade noninvasive (pTa) urothelial carcinoma group and 16 of the 17 cases with low-grade invasive urothelial carcinoma showed lamina propria invasion ( $\mathrm{pT} 1$ ) while one had muscularis propria invasion (pT2). The biopsy material of 6 of the 16 cases with low-grade invasive urothelial carcinoma and lamina propria invasion (pT1) has muscularis propria on the material while it had not been sampled in 10 .

We found no IMP3 staining in 20 cases diagnosed with lowgrade non-invasive urothelial carcinoma (Figure 1) and 14 cases with high-grade non-invasive urothelial carcinoma (Figure 2) along with 20 cases with benign urothelium. Staining was positive for IMP3 (Figure 3) in 2 (12.5\%) of the $16 \mathrm{pT} 1$ tumor cases in the low-grade invasive urothelial carcinoma group while there was no IMP3 staining in one pT2 tumor case. These two IMP3-positive low- 
grade invasive urothelial carcinoma, pT1 cases had both superficial and deep moderate staining. In the high-grade invasive urothelial carcinoma group, 9 of the 12 pT2 tumor cases (75\%) were IMP3 positive (Figure 4) while 2 of 9 pT1 tumor cases (25\%) were also IMP3 positive (Table I). The staining was deep and strong in 6 of the 9 pT2 cases in the IMP3-positive high-grade invasive urothelial carcinoma group while it was superficial and weak in 2 and superficial and strong in 1 . The IMP 3 staining of the $2 \mathrm{pT} 1$ cases in the same group was deep and strong in one and superficial and weak in the other.

Evaluation according to these data showed that $11.76 \%$ of low-grade invasive urothelial carcinoma cases and 55\% of high-grade invasive urothelial carcinoma cases had IMP3 expression while there was no staining in low/high grade

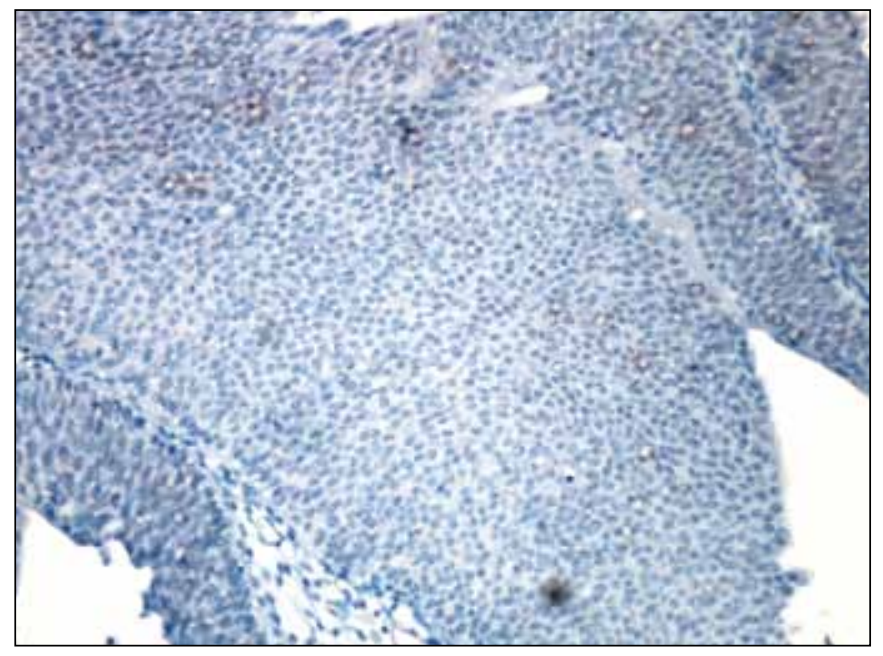

Figure 1: Low-grade non-invasive urothelial carcinoma (H\&E; $\mathrm{x} 200)$.

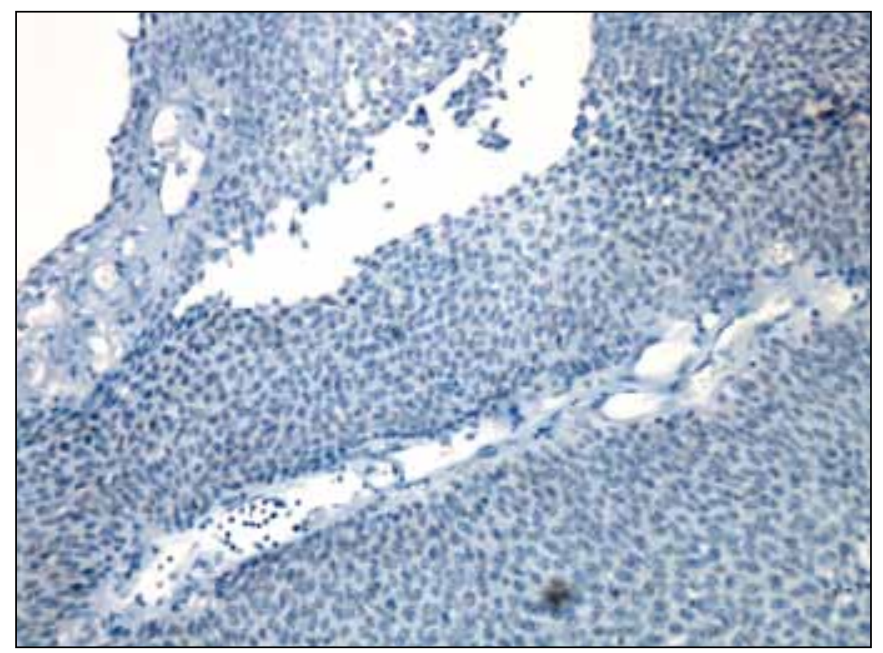

Figure 2: High-grade non-invasive urothelial carcinoma (H\&E; $\mathrm{x} 200)$. non-invasive tumors and benign urothelium. The statistical analysis with the $\chi^{2}$ test according to this distribution showed a statistically significant relationship between invasive tumors and IMP3 staining $(\mathrm{p}<0.000)$.

\section{DISCUSSION}

The incidence of bladder cancer is higher in developed countries and industrial communities and it is the 7th most common cancer in the world (1). Urothelial carcinomas appear in the form of Ta, Tis and $\mathrm{T} 1$ in more than $75 \%$ of the cases according to the TNM classification. Superficial tumors are quite benign while a high mortality rate has been reported with invasive tumors. The two most important factors in determining the behavior and treatment plan of bladder tumors are therefore the histopathological stage

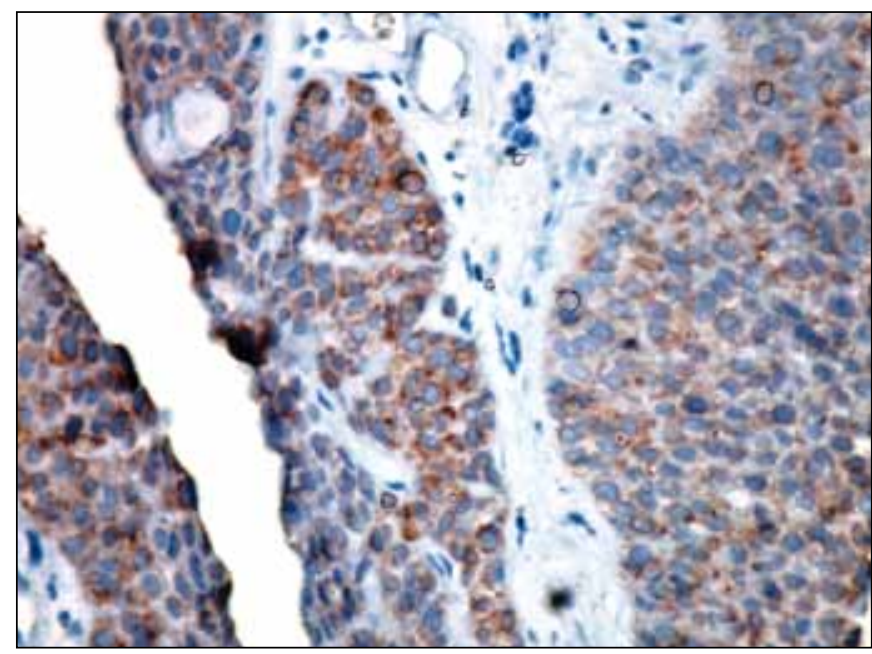

Figure 3: Low-grade invasive urothelial carcinoma (H\&E; x400).

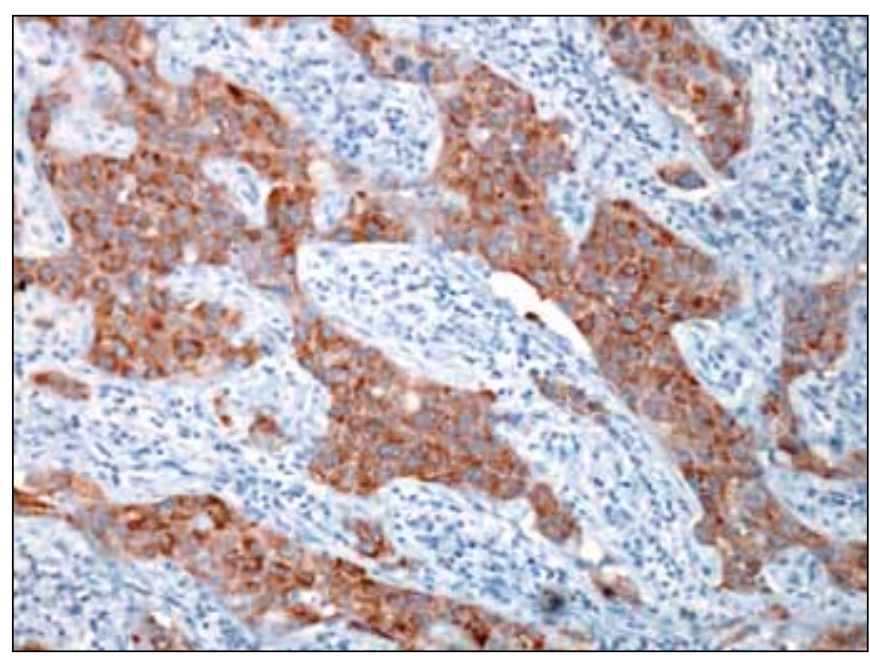

Figure 4: High-grade invasive urothelial carcinoma (H\&E; x200). 
Table I: Distribution of cases by IMP3 expression

\begin{tabular}{|l|c|c|c|c|c|c|c|}
\hline & $\begin{array}{c}\text { Benign } \\
\text { urothelium }\end{array}$ & $\begin{array}{c}\text { Low-grade } \\
\text { non-invasive } \\
\text { urothelial } \\
\text { carcinoma }\end{array}$ & \multicolumn{2}{|c|}{$\begin{array}{c}\text { Low-grade } \\
\text { invasive urothelial } \\
\text { carcinoma }\end{array}$} & $\begin{array}{c}\text { High-grade non- } \\
\text { invasive urothelial } \\
\text { carcinoma }\end{array}$ & $\begin{array}{c}\text { Low-grade } \\
\text { invasive } \\
\text { urothelial } \\
\text { carcinoma }\end{array}$ \\
\hline & & & pT1 & pT2 & & pT1 & pT2 \\
\hline IMP3 Positive & 0 & 0 & 2 & 0 & 0 & 2 & 9 \\
\hline IMP3 Negative & 20 & 20 & 14 & 1 & 14 & 6 & 3 \\
\hline Total & 20 & 20 & 16 & 1 & 14 & 8 & 12 \\
\hline
\end{tabular}

Table II: IMP expression in various tissues

\begin{tabular}{|c|c|c|c|c|c|}
\hline Organ & Normal tissue & Benign lesions & Malignant lesions & Method & Reference \\
\hline Thyroid & - & - & + & $\mathrm{IHC}$ & 12 \\
\hline $\begin{array}{l}\text { Hepatocellular } \\
\text { carcinoma }\end{array}$ & - & - & + & $\begin{array}{l}\text { IHC, WB, RT- } \\
\text { PCR, RNA } \\
\text { interference, cell } \\
\text { culture, tissue } \\
\text { microarray }\end{array}$ & 13 \\
\hline Biliary System & - & - & + & $\mathrm{IHC}$ & 14 \\
\hline $\begin{array}{l}\text { Skin-nevus } \\
\text { lesions }\end{array}$ & - & - & + & $\mathrm{IHC}$ & 15 \\
\hline $\begin{array}{l}\text { Exocrine } \\
\text { Pancreas }\end{array}$ & - & - & + & $\begin{array}{l}\text { IHC, NB, qRT- } \\
\text { PCR }\end{array}$ & 10,11 \\
\hline Oesophagus & - & - & + & IHC & 16 \\
\hline Lung & $\begin{array}{c}+ \text { (focal weak } \\
\text { in bronchial } \\
\text { epithelium) }\end{array}$ & & + & $\begin{array}{l}\text { IHC, WB, RT- } \\
\text { PCR, tissue } \\
\text { microarray }\end{array}$ & 17 \\
\hline Stomach & - & & + & IHC & 18 \\
\hline Colon-Rectum & $\begin{array}{c}+(\text { focal weak in } \\
\text { colon epithelium })\end{array}$ & & + & IHC & 19 \\
\hline Ovary & $\begin{array}{c}+ \text { (only in } \\
\text { follicular } \\
\text { epithelium) }\end{array}$ & & + & $\begin{array}{l}\text { IHC, tissue } \\
\text { microarray }\end{array}$ & 20 \\
\hline Testis & + & & + & IHC & 21 \\
\hline Hypophysis & $\begin{array}{c}+ \text { (especially in } \\
\text { small-medium } \\
\text { size chromophobe } \\
\text { cells) }\end{array}$ & $\begin{array}{l}+ \text { (especially in } \\
\text { GH, PRL and } \\
\text { TSH adenomas) }\end{array}$ & + & IHC, WB, RT-PCR & 22 \\
\hline
\end{tabular}

GH; growth hormone, PRL; prolactin, TSH; thyroid stimulating hormone, IHC; immunohistochemistry, WB; Western blot, NB; Nouthern blot, RT-PCR; real time-polymerase chain reaction. 
and grade (2). However, important differences have been shown between the biological behavior of Ta and T1 tumors as well (4). Fpr example, close follow-up and/or intravesical treatment is suggested following transurethral resection in the treatment of low-grade or Ta superficial urothelial carcinomas while more aggressive treatment options that include cystectomy and/or chemoradiotherapy is used for patients with a higher grade or T1 tumor that have a higher risk of progressing onto deep invasive cancer with a high mortality rate (2). This has led to the conclusion that some biological markers are needed in addition to the histopathological stage and grade in determining the behavior of urothelial carcinomas. This will enable determining beforehand the patients who will respond to effective treatment(4). Many tumor markers are currently been studied as potential markers for determining the prognosis of urothelial carcinomas. The most commonly studied one is p53 but literature data are still controversial. None of the markers used in the studies have resulted in clinical applications yet (5).

Invasive and non-invasive urothelial bladder cancers are known to develop through two separate pathways (6). A partial or total loss of chromosome $9 \mathrm{q}$ is a frequently encountered genetic event in low- or high-grade bladder tumors $(1,6)$. Loss of heterozygosity in chromosome $11 \mathrm{p}$ is seen in approximately $40 \%$ of some pT 1 tumors including pTa tumors while it is more common in tumors with high histopathological stage and grade (6).

Low-grade pTa tumors are genetically stable. Low-grade (pTa) tumors are known to develop following events that activate the Mitogen-activated Protein Kinase pathway such as H-ras mutations and Fibroblast growth factor receptor 3 mutations (6). The cyclin-dependent kinase inhibitor p16/CDKN2 (INK4a), an important cell cycle regulator and tumor suppressor gene, also plays an important role in the multistep carcinogenesis of papillary tumors (3).

Invasive tumors are genetically unstable tumors (6). A disturbance in the cell cycle control mechanism following DNA methyl transferase I upregulation and defects in the p53 and $\mathrm{Rb}$ pathways are accused of playing a role in the development of invasive tumors $(3,6)$. Missense mutations found in the $\mathrm{p} 53$ tumor suppressor gene have been detected in approximately $50 \%$ of bladder tumors with an unfavorable prognosis $(1,4)$. Overexpression of epiregulin that acts as a ligand for the epidermal growth factor receptor (EGFR) has also been shown to cause invasive and metastatic tumor development (7).
IMP3 is an oncofetal protein of the insulin-like growth factor (IGF)-II m-RNA binding protein family, just like IMP1 and IMP2 (8). Members of the IMP family are proteins that play an important role in RNA movement and stabilization, cell growth and cell migration in the early stages of embryogenesis (9). IMP3 is equivalent to the K homolog domain containing protein overexpressed in cancer (KOC) protein cloned from pancreatic tumors (10). IMP3, is secreted from the developing epithelium, muscle and placenta during human and mouse embryogenesis. It has been reported to be secreted at undetectably low levels from adult tissues $(8,9)$.

Expression of the IMP3 gene has first been defined by Gress et al. in pancreas cancers in 1996 (11). IMP3 is secreted in many other malignant tumors such as lung, gastric and colon cancers, renal cell carcinomas and soft tissue sarcomas while it is not expressed in benign tissues neighboring the tumor (Table II). Many studies have shown that IMP3 is associated with advanced stage and aggressive tumor behavior in the tumors it is secreted from $(3,4,8-10)$. These results indicate that the oncofetal protein IMP3 has a critical role in regulation of cell proliferation and tumor invasion. The role played by IMP3 in carcinogenesis is through stimulation of thyrosine phosphorylation by the IGF-I receptor and regulation of IGF-II gene expression through binding to the 5'-3' mRNA region of IGF-II (4). The thyrosine-phosphorylated IGF-I receptor sends mitogenic signals to the cell and stimulates cell proliferation and tumorigenesis (3).

We did not find IMP3 expression in benign urothelium or low- and high-grade non-invasive tumors in our study. IMP3 expression was present in $25 \%$ of the pT1 urothelial carcinomas and $75 \%$ of the pT2 urothelial carcinomas in the high-grade invasive group. IMP3 expression was found in $12.5 \%$ of the pT1 urothelial carcinomas in the low-grade invasive group while it was not present in only one pT2 urothelial carcinoma case in this group. This may seem to contradict the expression observed in the pT1 and pT2 urothelial carcinomas in the high-grade invasive group but the one negative IMP3 case in pT2 urothelial carcinomas may be due to tissue processing. The higher expression rate of IMP3 in deep invasive (pT2) urothelial carcinomas and the lack of expression in low- and high-grade noninvasive urothelial carcinomas and benign urothelium were statistically significant $(\mathrm{p}<0.000)$. Our results are consistent with those reported in the literature and indicate that it may be associated with aggressive tumor behavior in urothelial carcinomas. 
The 2007 study by Li et al. did not detect IMP3 expression in $99 \%$ of cases with a diagnosis of non-neoplastic urothelium or low-grade urothelial tumor while there was strong diffuse cytoplasmic staining with IMP3 in 54\% of the cases that had been diagnosed as high-grade urothelial tumor. They found a statistically significant difference regarding IMP3 expression between high-grade tumors and non-neoplastic urothelium and high-grade tumors and low-grade tumors similar to these findings. They also found a positive IMP expression rate of $49 \%$ in superficial (pTa and pT1) tumors and $78 \%$ in deep invasive tumors (pT2 or higher tumors). However, this difference was not statistically significant. Li et al. state in light of these findings that IMP3 may play a role in tumor progression more than in tumor initiation (3).

A study by Sitnikova et al. in 2008 investigated the biopsy material of 214 patients who received a diagnosis of urothelial carcinoma of the bladder regarding the IMP3 expression profile. They found no IMP3 expression in benign urothelial tissues adjacent to the urothelial carcinoma. IMP3 expression was found in $16 \%$ of $\mathrm{Ta}$ urothelial carcinomas, $35 \%$ of $\mathrm{T} 1$ urothelial carcinomas and $36 \%$ of $\mathrm{T} 1$ urothelial carcinoma in situ cases among the superficial urothelial carcinoma group while it was present in $93 \%$ of metastatic urothelial carcinomas. IMP3 expression was found to correlate between the markers known to be unfavorable prognostic factors (age, gender, tumor size, tumor multicentricity, tumor histopathological stage and grade, response to intravesical treatment) in superficial urothelial carcinomas. Superficial urothelial carcinomas that expressed IMP3 were found to have 6 times the risk of progressing to deep invasive cancer or metastasize compared to those that did not express IMP3. Metastatic disease was found during follow-up in $60 \%$ of IMP3 positive cases that received a diagnosis of T1 urothelial carcinoma while metastasis was not found in any IMP3 negative case. Sitnikova et al. state in light of these findings that IMP3 may play a direct role in the progression and metastasis of urothelial carcinomas (4).

The 5-year survival among high-risk superficial urothelial carcinomas that undergo early cystectomy is about $90 \%$ $(23,24)$. However, the quality of life decreases markedly in patients who undergo cystectomy and the patients can also die because of cystectomy-related complications $(2,25,26)$. It is therefore important to determine in the early stages the patients with superficial urothelial carcinoma who have high risk and whose tumors will have an unfavorable prognosis. The assessment of IMP3 expression can be a helpful marker to determine the disease course beforehand and decide on the best therapeutic option when it is difficult to choose between intravesical treatment and cystectomy options in superficial urothelial carcinomas and especially when the biopsy sample is small and superficial and does not contain muscularis propria. IMP3 immunohistochemical staining is also an inexpensive and reliable method that is easy to use in routine practice. The material obtained from TUR used in the treatment of superficial urothelial carcinomas is also an appropriate material for routine immunohistochemical analysis. The use of standard staining protocols and fully automatic staining devices can minimize any conflicts between staining results.

\section{REFERENCES}

1. Lopez-Beltran A, Sauter G, Gasser T, Hartmann A, SchmitzDrager BJ, Helpap B, Ayala AG, Tamboli P, knowles MA, Sidransky D, Cordon-Cardo C, Jones PA, Cairns P, Simon R, Amin MB, Tycynski JE: Infiltrating urothelial carcinoma. In Eble JN, Sauter G, Epstein JI, Sesterhenn IA (eds): Tumors of the Genito-Urinary and Male Genital Organs. Lyon, IARC Press, 2004, 93-109

2. Sengupta S, Blute $M L$ : The management of superficial transitional cell carcinoma of the bladder. Urology 2006, 67: 48-54

3. Li L, Xu H, Spaulding BO, Cheng L, Simon R, Yao JL, di Sant'Agnese PA, Bourne PA, Huang J: Expression of RNAbinding protein IMP3 (KOC) in benign urothelium and urothelial tumors. Hum Pathol 2008, 39:1205-1211

4. Sitnikova L, Mendese G, Liu Q, Woda BA, Lu D, Dresser K, Mohanty S, Rock KL, Jiang Z: IMP3 predicts aggressive superficial urothelial carcinoma of the bladder. Clin Cancer Res 2008, 14:1701-1706

5. Habuchi T, Marberger M, Droller MJ, Hemstreet GP 3rd, Grossman HB, Schalken JA, Schmitz-Dräger BJ, Murphy WM, Bono AV, Goebell P, Getzenberg RH, Hautmann SH, Messing E, Fradet Y, Lokeshwar VB: Prognostic markers for bladder cancer: International Consensus Panel on bladder tumor markers. Urology 2005, 66:64-74

6. Knowles MA: Molecular subtypes of bladder cancer: Jekyll and Hyde or chalk and cheese? Carcinogenesis 2006, 27: 361-373

7. Nicholson BE, Frierson HF, Conaway MR, Seraj JM, Harding MA, Hampton GM, Theodorescu D: Profiling the evolution of human metastatic bladder cancer. Cancer Res 2004, 64: 7813-7821

8. Nielsen J, Christiansen J, Lykke-Andersen J, Johnsen AH, Wewer UM, Nielsen FC: A family of insulin-like growth factor II mRNAbinding proteins represses translation in late development. Mol Cell Biol 1999, 19: 1262-1270

9. Mueller-Pillasch F, Pohl B, Wilda M, Lacher U, Beil M, Wallrapp C, Hameister H, Knöchel W, Adler G, Gress TM: Expression of the highly conserved RNA binding protein KOC in embryogenesis. Mech Dev 1999, 88:95-99

10. Müeller-Pillasch F, Lacher U, Wallrapp C, Micha A, Zimmerhackl F, Hameister H, Varga G, Friess H, Büchler M, Beger HG, Vila MR, Adler G, Gress TM: Cloning of a gene highly overexpressed in cancer coding for a novel $\mathrm{KH}$-domain containing protein. Oncogene 1997, 14:2729-2733 
11. Yantiss RK, Woda BA, Fanger GR, Kalos M, Whalen GF, Tada H, Andersen DK, Rock KL, Dresser K: KOC (K homology domain containing protein overexpressed in cancer): a novel molecular marker that distinguishes between benign and malignant lesions of the pancreas. Am J Surg Pathol 2005, 29: 188-195

12. Slosar M, Vohra P, Prasad M, Fischer A, Quinlan R, Khan A: Insulin-like growth factor mRNA binding protein 3 (IMP3) is differentially expressed in benign and malignant follicular patterned thyroid tumors. Endocr Pathol 2009, 20: 149-157

13. Jeng YM, Chang CC, Hu FC, Chou HY, Kao HL, Wang TH, Hsu HC: RNA-binding protein insulin-like growth factor II mRNAbinding protein 3 expression promotes tumor invasion and predicts early recurrence and poor prognosis in hepatocellular carcinoma. Hepatology 2008, 48:1118-1127

14. Riener MO, Fritzsche FR, Clavien PA, Pestalozzi BC, ProbstHensch N, Jochum W, Kristiansen G: IMP3 expression in lesions of the biliary tract: a marker for high-grade dysplasia and an independent prognostic factor in bile duct carcinomas. Hum Pathol 2009, 40:1377-1383

15. Pryor JG, Bourne PA, Yang Q, Spaulding BO, Scott GA, Xu H: IMP-3 is a novel progression marker in malignant melanoma. Mod Pathol 2008, 21: 431-437

16. Lu D, Vohra P, Chu PG, Woda B, Rock KL, Jiang Z: An oncofetal protein IMP3: a new molecular marker for the detection of esophageal adenocarcinoma and high-grade dysplasia. Am J Surg Pathol 2009, 33: 521-525

17. Wang T, Fan L, Watanabe Y, McNeill PD, Moulton GG, Bangur C, Fanger GR, Okada M, Inoue Y, Persing DH, Reed SG: L523S, an RNA-binding protein as a potential therapeutic target for lung cancer. Br J Cancer 2003, 88: 887-894

18. Jeng YM, Wang TH, Lu SH, Yuan RH, Hsu HC: Prognostic significance of insulin-like growth factor II mRNA-binding protein 3 expression in gastric adenocarcinoma. Br J Surg 2009, 96: 66-73
19. Yuan RH, Wang CC, Chou CC, Chang KJ, Lee PH, Jeng YM: Diffuse expression of RNA-binding protein IMP3 predicts highstage lymph node metastasis and poor prognosis in colorectal adenocarcinoma. Ann Surg Oncol 2009, 16: 1711-1719

20. Köbel M, Xu H, Bourne PA, Spaulding BO, Shih IeM, Mao TL, Soslow RA, Ewanowich CA, Kalloger SE, Mehl E, Lee CH, Huntsman D, Gilks CB: IGF2BP3 (IMP3) expression is a marker of unfavorable prognosis in ovarian carcinoma of clear cell subtype. Mod Pathol 2009, 22:469-475

21. Yaniv K, Yisraeli JK: The involvement of a conserved family of RNA binding proteins in embryonic development and carcinogenesis. Gene 2002, 287: 49-54

22. Righi A, Zhang S, Jin L, Scheithauer BW, Kovacs K, Kovacs G, Goth MI, Korbonits M, Lloyd RV: Analysis of IMP3 expression in normal and neoplastic human pituitary tissues. Endocr Pathol 2010, 21:25-31

23. Amling CL, Thrasher JB, Frazier HA, Dodge RK, Robertson JE, Paulson DF: Radical cystectomy for stages Ta, Tis and T1 transitional cell carcinoma of the bladder. J Urol 1994, 151: 31-35

24. Freeman JA, Esrig D, Stein JP, Simoneau AR, Skinner EC, Chen SC, Groshen S, Lieskovsky G, Boyd SD, Skinner DG: Radical cystectomy for high risk patients with superficial bladder cancer in the era of orthotopic urinary reconstruction. Cancer 1995, 76:833-839

25. Herr HW, Sogani PC: Does early cystectomy improve the survival of patients with high risk superficial bladder tumors? J Urol 2001, 166: 1296-1299

26. Stockle M, Alken P, Engelmann U, Jacobi GH, Riedmiller H, Hohenfellner R: Radical cystectomy-often too late? Eur Urol 1987, 13: 361-367 